Research Article

\title{
Analysis of paternal lineages in Brazilian and African populations
}

\author{
Mónica Carvalho ${ }^{1}$, Pedro Brito ${ }^{1}$, Virgínia Lopes ${ }^{1}$, Lisa Andrade ${ }^{1}, \mathrm{M}^{\mathrm{a}}$ João Anjos ${ }^{1}$, \\ Francisco Corte Real ${ }^{2,3}$ and Leonor Gusmão ${ }^{4}$ \\ ${ }^{1}$ Forensic Genetics Service, Centre Branch, National Institute of Legal Medicine, Coimbra, Portugal. \\ ${ }^{2}$ National Institute of Legal Medicine, Coimbra, Portugal. \\ ${ }^{3}$ Faculty of Medicine, University of Coimbra, Coimbra, Portugal. \\ ${ }^{4}$ Institute of Pathology and Molecular Immunology, University of Porto, Porto, Portugal.
}

\begin{abstract}
The present-day Brazilian population is a consequence of the admixture of various peoples of very different origins, namely, Amerindians, Europeans and Africans. The proportion of each genetic contribution is known to be very heterogeneous throughout the country. The aim of the present study was to compare the male lineages present in two distinct Brazilian populations, as well as to evaluate the African contribution to their male genetic substrate. Thus, two Brazilian population samples from Manaus (State of Amazon) and Ribeirão Preto (State of São Paulo) and three African samples from Guinea Bissau, Angola and Mozambique were typed for a set of nine $Y$ chromosome specific STRs. The data were compared with those from African, Amerindian and European populations. By using Y-STR haplotype information, low genetic distances were found between the Manaus and Ribeirão Preto populations, as well as between these and others from lberia. Likewise, no significant distances were observed between any of the African samples from Angola, Mozambique and Guinea Bissau. Highly significant Rst values were found between both Brazilian samples and all the African and Amerindian populations. The absence of a significant Sub-Saharan African male component resulting from the slave trade, and the low frequency in Amerindian ancestry $Y$-lineages in the Manaus and Ribeirão Preto population samples are in accordance with the accentuated gender asymmetry in admixture processes that has been systematically reported in colonial South American populations.
\end{abstract}

Key words: chromosome Y, STRs, lineages, Brazil, Africa.

Received: August 19, 2009; Accepted: February 23, 2010.

\section{Introduction}

South America was already inhabited when the first European settlers arrived. The first of these, more specifically the Portuguese, landed in Brazil in 1500, in territory already occupied by Amerindians. The region was quickly colonized, with the intention to explore its natural resources. Throughout the history different people from all over the world arrived at this territory, especially in the colonial period, with a great affluence from Africa due to the slave trade, thereby initiating the admixture of Amerindians, Africans and Europeans. In the $16^{\text {th }}$ century, on the occasion of the arrival of the Portuguese, the native population was around 2.5 million. Between the $16^{\text {th }}$ and $19^{\text {th }}$ centuries, about 4 million Sub-Saharan African slaves arrived in Brazil (IBGE, 2000). Initially, admixture was mainly between native females and Portuguese male navigators, due to the insignificant immigration of European women (Car-

Send correspondence to Mónica Carvalho. Forensic Genetics Service, Centre Branch, National Institute of Legal Medicine, Largo da Sé Nova, 3000-213 Coimbra, Portugal. E-mail: monica.carvalho@ dcinml.mj.pt.
valho-Silva et al., 2001). The subsequent migration contributed to a constant influx of both Africans and Europeans, thereby giving rise to the present very heterogeneous population, due to the different proportions of local admixture throughout the country (Ribeiro, 1995).

In this work, we attempted to study this historic influence on the genetic background of present-day populations, by analyzing two Brazilian populations, one from Manaus (State of Amazon) and the other from Ribeirão Preto (State of São Paulo). Three African populations, from Guinea Bissau, Angola and Mozambique were also included in the study, since they represent the ancestral populations of most Africans that arrived in Brazil during the period of the slave trade. The five populations were genetically characterized for Y chromosome specific STR loci by typing 9 markers (DYS19, DYS389 I, DYS389 II, DYS390, DYS391, DYS392, DYS393 and DYS385, the latter including 2 loci), whereas the Brazilian samples were typed for five SNP markers (M2, M3, M35, M213 and SRY10831). In order to evaluate the possible male contributions to our samples, a comparison was made between 
our data and those already available for Brazilian, Amerindian, African and European populations.

\section{Materials and Methods}

\section{DNA samples}

The Y-chromosomal minimal haploptype was defined by 9 Y- STRs (DYS19, DYS389 I, DYS389 II, DYS390, DYS391, DYS392, DYS393, DYS385) in unrelated individuals from Manaus $(\mathrm{N}=42)$, Ribeirão Preto $(\mathrm{N}=65)$, Guinea Bissau $(\mathrm{N}=32)$, Angola $(\mathrm{N}=48)$ and Mozambique $(\mathrm{N}=36)$. The samples from Brazil, Guinea Bissau and Mozambique were collected in district hospitals. The Brazilian samples were composed of individuals from the cities Manaus and Ribeirão Preto. The African samples from Guinea Bissau and Mozambique consisted of individuals living in the regions of Bissau and Maputo, respectively. The samples from Angola were collected in the northern region of the country, and included individuals from the villages of N'Dalatando and Lucala, in Kwanza province, and from the province of Uíge. Blood samples were obtained with written informed consent.

\section{Marker typing}

For samples from Manaus and Ribeirão Preto, the minimal haplotype was typed using a PowerPlexY PCR Amplification Kit (Promega), with primers and amplification conditions according to manufacturer's instructions. As regards the others from Guinea Bissau, Angola and Mozambique, the STRs DYS19, DYS389 I, DYS389 II, DYS390 and DYS393 were amplified as described by Gusmão et al. (1999). DYS385 amplification conditions complied with the methodology, as described by Schneider et al. (1998), whereas multiplex amplification of DYS391, DYS392, DYS393 was according to Kloosterman et al. (1998). Alleles were designated according to the International Society for Forensic Genetics (ISFG) guidelines for forensic analysis using Y-STRs (Gusmão et al., 2006). For defining male haplogroups in population samples from Manaus and Ribeirão Preto, five Y-chromosome SNP markers (M2, M3, M35, M213 and SRY10831) were genotyped using methods as described by Silva et al. (2006). Haplogroup nomenclature was according to Karafet et al. (2008).

\section{Statistical analysis}

Both haplotype diversity, according to Nei (1987), and pairwise Rst genetic distances were calculated using Arlequin v. 3.0 software Excoffier et al. (2005), without considering DYS385. R $\mathrm{R}_{\mathrm{ST}}$ genetic distances were visualized in two-dimensional space by using the Multi DimensionalScaling (MDS) method included in the StatSoft, Inc. (2007) STATISTICA data analysis software system, version 8.0.

\section{Results and Discussion}

\section{$\mathrm{Y}$ haplotype diversity}

The haplotype results obtained for the STRs (DYS19, DYS389 I, DYS389 II, DYS390, DYS391, DYS392, DYS393 and DYS385) are provided as Supplementary Material (Tables S1 to S5). Haplotype diversity was estimated in all studied populations (Table 1). A comparison of haplotype diversity revealed high levels in Manaus and Ribeirão Preto, comparable to that observed in the African samples. Although higher diversity could be expected in African samples, the presence of male lineages of different origins in the Brazilian populations might have contributed to incrementing diversity.

In the sample from Manaus, all individuals presented different haplotypes (42 unique ones) with overall haplotype diversity of $1.000 \pm 0.0052$. In Ribeirão Preto, 58 different haplotypes were observed, 54 of which unique. In Ribeirão Preto, the most common haplotypes represented in more than one individual (RP1, RP5, RP6 and RP19 - Table S2) correspond to or are just a few steps apart from, the most frequent haplotype in all Iberian populations (Gusmão et al. 2003), which represents the core haplotype within the R1b1b2-M269 haplogroup. In Manaus, this core haplotype was encountered in only one individual (M3), whereas one or two step neighbors were found in 10 individuals (M1, M4, M10, M21, M22, M30, M37, M38, M39 and M42). Therefore, by analyzing this set of Y-STRs, it is possible to infer an important male-mediated European genetic influx in both of the Brazilian populations studied.

29 different haplotypes were observed in the Guinea Bissau population, 27 of which unique. In Angola, there were 42 different haplotypes, 36 unique. Finally, in Mo-

Table 1 - Number of different and unique haplotypes, and haplotype diversity in population samples from Manaus, Ribeirão Preto, Guinea Bissau, Angola and Mozambique.

\begin{tabular}{llccc}
\hline Population & $\mathrm{N}$ & Number of different haplotypes & Number of unique haplotypes & Haplotype diversity \\
\hline Manaus & 42 & 42 & 42 & $1.0000 \pm 0.0052$ \\
Ribeirão Preto & 65 & 58 & 54 & $0.9947 \pm 0.0044$ \\
Guinea Bissau & 32 & 29 & 27 & $0.9919 \pm 0.0110$ \\
Angola & 48 & 42 & 36 & $0.9947 \pm 0.0054$ \\
Mozambique & 36 & 34 & 32 & $0.9968 \pm 0.0075$ \\
\hline
\end{tabular}


zambique 32 unique haplotypes were observed from a total of 34 different ones. Four different haplotypes are shared between Angola and Mozambique, and one between Angola and Guinea Bissau. Three of these shared haplotypes match the Bantu core described by Thomas et al. (2000), besides one differing by only one mutation step. When searching for shared haplotypes between African and Brazilian samples, a single hit was found between Angola and Manaus (M25= A20), this also matching the Bantu modal. Apart from this haplotype found in Manaus, a search in both Brazilian samples did not reveal the presence of any other haplotype corresponding to the Bantu core. Only one haplotype was found in Ribeirão Preto that differed by a single step from the Bantu modal. Therefore, based on Y-STR results, a significant male-mediated African genetic influx could not be expected in both of these Brazilian populations.

\section{Population comparison}

The population samples from Manaus, Ribeirão Preto, Guinea Bissau, Mozambique and Angola were compared with different populations (listed in Table 2) through pairwise $\mathrm{R}_{\mathrm{ST}}$ genetic distance analysis. The results obtained showed no significant differences between Manaus and Ribeirão Preto $\left(\mathrm{R}_{\mathrm{ST}}=0.0002, \mathrm{p}=0.4030\right)$. The same was observed when comparing these two populations with other urban and/or admixed South American (codes 3, 4, 5, 6, 7 and 12 in Table 2) or Iberian (13, 14, 15 and 16 - Table 2) populations, with $\mathrm{R}_{\mathrm{ST}}$ values below $0.0011(\mathrm{p}>0.0059)$. Among other American populations, a significant differentiation was found between Manaus or Ribeirão Preto, and African descendents from Rio de Janeiro $\left(\mathrm{R}_{\mathrm{ST}}>0.0817\right.$, $\mathrm{p}=0.0002$ ) and South Amerindians (populations 9, 10 and 11 in Table 2), $\mathrm{R}_{\mathrm{ST}}>0.0997(\mathrm{p}=0.0015)$.

Within the African group, although p-values were not significant $(p>0.01)$, higher $R_{S T}$ values were observed between the Guinea Bissau, Angola and Mozambique samples $\left(0.00998<\mathrm{R}_{\mathrm{ST}}<0.05381\right)$ than those observed between the Brazilian and European samples. Highly significant $R_{S T}$ values were found when comparing the Manaus and Ribeirão Preto with all the African populations $\left(\mathrm{R}_{\mathrm{ST}}>0.1311, \mathrm{p}=0.0000\right)$.

In multidimensional scaling (MDS) plot of pairwise $\mathrm{R}_{\mathrm{ST}}$ genetic distances, based on Y-STR data (Figure 1), it is possible to note the formation of different clusters, these including a European and an African group, as well as two

Table 2 - List of South American, African and European populations used in population comparison analysis.

\begin{tabular}{llcl}
\hline Code & Population & $\mathrm{N}$ & Reference \\
\hline 1 & Manaus - Brazil, State of Amazon & 42 & this study \\
2 & Ribeirão Preto - Brazil, State of São Paulo & 65 & this study \\
3 & Santa Catarina - Brazil, State of Santa Catarina & 109 & Cainé et al., 2005 \\
4 & Belém - Brazil, State of Pará & 200 & Palha et al., 2007 \\
5 & Rio de Janeiro - Brazil, State of Rio de Janeiro & 245 & Goes et al., 2005 \\
6 & São Paulo - Brazil, State of São Paulo & 200 & Gois et al., 2007 \\
7 & Rio Grande Sul - Brazil, State of Rio Grande do Sul & 203 & Leite et al., 2008 \\
8 & Rio de Janeiro - Brazil, State of Rio de Janeiro (African descendents) & 135 & Domingues et al., 2007 \\
9 & Rio Grande do Sul - Brazil, Guarani and Kaingang (Amerindians) & 42 & Leite et al., 2008 \\
10 & Argentina, northern region, Colla - (Amerindians) & 48 & Toscanini et al., 2008 \\
11 & Argentina, northwestern region, Toba (Amerindians) & 49 & Toscanini et al., 2008 \\
12 & Buenos Aires - Argentina & 100 & Sanchez-Diz et al., 2008 \\
13 & Portugal, northern region & 244 & Sanchez-Diz et al., 2008 \\
14 & Portugal, central region & 100 & Bento et al., 2009 \\
15 & Portugal, southern region & 100 & Sanchez-Diz et al., 2008 \\
16 & Spain & 148 & Martin et al., 2004 \\
17 & Guinea Bissau & 32 & this study \\
18 & Angola & 48 & this study \\
19 & Mozambique & 36 & this study \\
20 & Guinea Equatorial & 101 & Arroyo Pardo et al., 2005 \\
21 & Cabinda - Angola & 208 & Beleza, 2005 \\
23 & Maputo - Mozambique, & 112 & Alves et al., 2003 \\
24 & São Tome and Principe & 103 & Trovoada et al., 2001 \\
\hline & Cape Verde & 47 & Corte-Real et al., 2000 \\
\hline
\end{tabular}




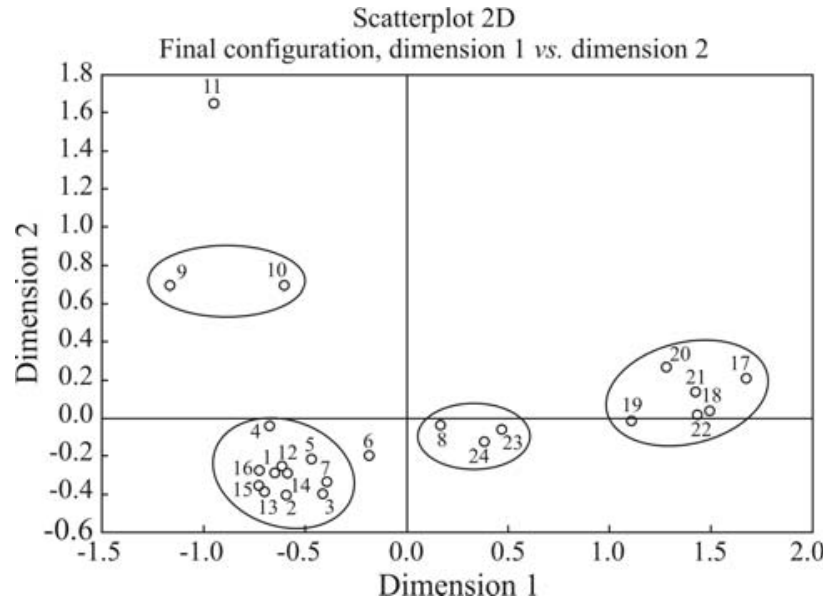

Figure 1 - MDS plot based on population pairwise Rst values. Clusters are indicated for populations that did not significantly differ in comparison analysis based on $\mathrm{R}_{\mathrm{ST}} \mathrm{p}$-values. Population codes are indicated in Table 2 .

other clusters formed by European/Amerindian and European/African mixed populations. As expected, populations from the Guinea Bissau, Angola and Mozambique groups are on a line with other populations from continental Africa. Manaus and Ribeirão Preto clearly group with European populations from Iberia, together with other urban population samples from South America. These two populations stand well apart from the remaining clusters of African, Amerindian or admixed ancestry.

\section{Y-SNP haplogroups in the Brazilian populations}

Five SNPs were typed in the Manaus and Ribeirão Preto samples, in order to trace the origin of the Y-chromosomes in the current population. In each population sample, a single chromosome belonged to the most frequent SubSaharan African haplogroups by carrying the M2 mutation (Tables S1 and S2). In Ribeirão Preto, a second African lineage could be found, which lacks the M213 and SRY10831 mutations, therefore being classified in paragroup $\mathrm{A}^{*}$. One out of 65 samples from Ribeirão Preto and 4 out of 42 from Manaus carried both the M213 and M3 mutations that characterize Amerindian haplogroups. The remaining samples, were classified in $\mathrm{F}^{*}$ (except Q3), E1b1b1 - M35 or $\mathrm{Y}^{*}$ (xA, E1b1a-b1, F*).

Based on the SNP results, we concluded that Europe is the main source of paternal lineages existing in the present-day population of Ribeirão Preto (95.4\%), with African and Amerindian lineages only representing $3.1 \%$ and $1.5 \%$ of the chromosomes, respectively. In Manaus, the origin of most chromosomes can also be traced to Europe (88.1\%), although a higher Amerindian component was found (9.5\%). Only a single African-ancestry chromosome $(2.4 \%)$ was detected in the sample from Manaus.

\section{Conclusions}

Many studies have been carried out to characterize the genetic diversity of Brazilian populations aiming to better understand colonization processes and the demographic history of its native populations (e.g. Bortolini et al. 2003; Abe-Sandes et. al. 2004; Silva et al. 2006). These studies systematically revealed a particularly sub-structured country, with populations from distinct regions differing in their proportion of African, Amerindian and European ancestries. Studies of mtDNA and Y-chromosome markers also revealed much higher genetic differentiation at the maternal gene-pool level than at the paternal counterpart (Marrero et al. 2005). Indeed, as regards Y chromosome lineage, a high European contribution was observed in most Brazilian samples. This was also evident in the present study, where Brazilian samples, as well as all other general population samples countrywide, presented much lower genetic distances when compared with Europeans than with Africans or Amerindians. A European contribution was also evident in the South Amerindian sample studied by Leite et al. (2008) which presented a similar distance $\left(\mathrm{R}_{\mathrm{ST}}=0.18\right)$ to the Toba Amerindian sample and any of the Iberian samples. Nevertheless, from the SNP results it can be inferred that, although genetic distance analysis based on STR profiles allowed to identify the main European contribution to the Brazilian samples, it was not able to detect minor contributions. In fact, the almost $10 \%$ Amerindian contribution to the Manaus sample was insufficient to produce significant genetic distance values between Manaus and both Ribeirão Preto or Iberian populations.

The absence of a significant Sub-Saharan African male component resulting from the slave trade or Amerindian ancestry Y-lineages, in the Manaus and Ribeirão Preto population samples, is in accordance with pronounced gender asymmetry in admixture processes that has been systematically reported in colonial South American populations.

\section{Acknowledgments}

We acknowledge funding by Fundação para a Ciência e a Tecnologia, POCI 2010.

\section{References}

Abe-Sandes K, Silva WA and Zago MA (2004) Heterogeneity of the Y chromosome in Afro-Brazilian populations. Hum Biol 76:77-86.

Alves C, Gusmão L, Barbosa J and Amorim A (2003) Evaluating the informative power of Y-STRs: A comparative study using European and new African haplotype data. Forensic Sci Int 134:126-133.

Arroyo-Pardo E, Gusmão L, López-Parra AM, Baeza C, Mesa MS and Amorim A (2005) Genetic variability of 16 Y-chromosome STRs in a sample from Equatorial Guinea (Central Africa). Forensic Sci Int 149:109-113. 
Beleza S (2005) Phylogenetic and demographic history of two human populations revealed by the analysis of two non-recombining segments of the genome: Y-chromosome and mitochondrial DNA. PhD Thesis, University of Santiago de Compostela, 230 pp.

Bento AM, Carvalho M, Lopes V, Serra A, Afonso Costa H, Andrade L, Balsa F, Oliveira C, Batista L, Gamero J, et al (2009) Distribution of Y chromosomal haplotypes in the Central Portuguese population using 17-STRs. Forensic Sci Int Genet 4:e35-e36.

Bortolini MC, Salzano FM, Thomas MG, Stuart S, Nasanen SPK, Bau CHD, Hutz MH, Layrisse Z, Petzl-Erler M, Tsuneto LT, et al. (2003) Y-chromosome evidence for differing ancient demographic histories in the Americas. Am J Hum Genet 73:524-539.

Cainé L, Corte-Real F, Vieira DN, Carvalho M, Serra A, Lopes V and Vide MC (2005) Allele frequencies and haplotypes of 8 Y-chromosomal STRs in the Santa Catarina population of southern Brazil. Forensic Sci Int 148:75-79.

Carvalho-Silva DR, Santos FR, Rocha J and Pena SDJ (2001) The phylogeography of Brazilian Y-Chromosome lineages. Am J Hum Genet 68:281-286.

Corte Real F, Carvalho M, Andrade L, Anjos MJ, Pestoni C, Lareu MV, Carracedo A, Vieira DN and Vide MC (2000) Chromosome-Y STRs anlysis and evolutionary aspects for Portuguese speaking countries. In: Sensabaugh GF, Lincoln $\mathrm{P}$ and Olaisen B (eds) Progress in Forensic Genetics, v. 8. Elsevier, Amsterdam, pp 272-274.

Domingues PM, Gusmão L, Silva DA, Amorim A, Pereira R and Carvalho EF (2007) Sub-Sharan Africa descendents in Rio de Janeiro (Brazil): Population and mutational data for 12 Y-STR loci. Int J Legal Med 121:238-241.

Excoffier L, Laval G and Schneider S (2005) Arlequin v. 3.0: An integrated software package for population genetics data analysis. Evol Bioinform Online 1:47-50.

Góes ACS, Carvalho EF, Gomes I, Silva DA, Gil EHF, Amorim A and Gusmão L (2005) Population and mutational analysis in 17 Y-STR loci from Rio de Janeiro (Brazil). Int J Legal Med 119:70-76.

Góis CC, Martins JA, Pereira GA, Freschi A, Paneto GG, Alvarenga VLS, Cicarelli RMB, Hirata $\mathrm{MH}$ and Oliveira RN (2008) Genetic population data of 12 STR loci of the Power Plex Y system in the state of São Paulo population (Southeast of Brazil). Forensic Sci Int 174:80-85.

Gusmão L, Gonzalez-Neira A, Pestoni C, Brión M, Lareu MV and Carracedo A (1999) Robustness of the Y STRs DYS19, DYS389 I and II, DYS390 and DYS393: Optimization of a PCR pentaplex. Forensic Sci Int 106:163-172.

Gusmão L, Sánchez-Diz P, Alves C, Beleza S, Lopes A, Carracedo A and Amorim A (2003) Grouping of Y-STR haplotypes European geographic clines. Forensic Sci Int 134:172-179

Gusmão L, Butler JM, Carracedo A, Gill P, Kayser M, Mayr WR, Morling N, Prinz M, Roewer L, Tyler-Smith C, et al. (2006) DNA Commission of International Society of Forensic Genetics (ISFG): An update of recommendations on the use of Y-STRs in forensic analysis. Forensic Sci Int 157:187-197.

IBGE - Instituto Brasileiro de Geografia Estatística (2000) Brasil: 500 anos de povoamento. In: Apêndice: Estatisticas de 500 Anos de Povoamento. IBGE, Rio de Janeiro, pp 221-223.
Leite FPN, Callegari-Jacques SM, Carvalho BA, Kommers T, Matte CHF, Raimann PE, Schwengber SP, Sortica VA, Tsuneto LT, Petzl-Erler ML, et al. (2008) Y-STR Analysis in Brazilian and Ameridian Populations. Am J Hum Biol 20:359-363.

Karafet TM, Mendez FL, Meilerman MB, Underhill PA, Zegura SL and Hammer MF (2008) New binary polymorphisms reshape and increase resolution of the human Y chromosomal haplogroup tree. Genome Res 18:830-838.

Kloosterman AD, Pouwels M, Daselaar P and Jansen HJT (1998) Population genetic study of Y-chromosome specific STR loci in Dutch Caucasians. In: Olaisen B, Brinkmann B and Lincoln P (eds), Progress in Forensic Genetics, v. 7. Elsevier, Amsterdam, pp 491-493.

Marrero AR, Leite FPN, Carvalho BA, Peres LM, Kommers TC, Cruz IM, Salzano FM, Ruiz-Linares A, Júnior WAS and Bortolini MC (2005) Heterogeneity of the genome ancestry of individuals classified as white in the state of Rio Grande do Sul, Brazil. Am J Hum Biol 17:496-506.

Martín P, García-Hirschfeld J, García O, Gusmão L, García P, Albarrán C, Sancho M and Alonso A (2004) A Spanish population study of 17 Y-chromosome STR loci. Forensic Sci Int 139:231-235.

Nei M (1987) Molecular Evolutionary Genetics. Columbia University Press, New York, 512 pp.

Palha TJBF, Rodrigues EMR and Santos SEB (2007) Y- chromosomal STR haplotypes in a population from Amazon region, Brazil. Forensic Sci Int 166:233-239.

Ribeiro D (1995) O Povo Brasileiro: A Formação e o Sentido do Brasil. Companhia das Letras, São Paulo, 480 pp.

Sánchez-Diz P, Alves C, Carvalho E, Carvalho M, Espinheira R, García O, Pontes L, Porto MJ, Santapa O, et al (2008) Population and segregation data on 17 Y-STRs: Results of a GEP-ISFG collaborative study. Int J Legal Med 122:529533.

Schneider PM, Meuser S, Waiyawuth W, Seo Y and Rittner C (1998) Tandem repeat structure of the duplicate chromosomal STR locus DYS385 and frequency studies in the German and three Asian populations. Forensic Sci Int 97:61-70.

Silva DA, Carvalho E, Costa G, Tavares L, Amorim A and Gusmão L (2006) Y- chromosome genetic variation in Rio de Janeiro population. Am J Hum Biol 18:829-837.

Thomas MG, Parfitt T, Weiss DA, Skorecki K, Wilson JF, Roux M, Bradman N and Goldstein DB (2000) Y Chromosomes traveling south: The Cohen Modal Haplotype and the origins of the Lemba-the "Black Jews of Southern Africa". Am J Hum Genet 66:674-686.

Toscanini U, Gusmão L, Berardi G, Amorim A, Carracedo A, Salas A and Raimundi E (2008) Y chromosome microsatellite genetic $\mathrm{Y}$ variation in two Native American populations from Argentina: Population stratification and mutation data. Forensic Sci Int Genet 2:274-280.

Trovoada MJ, Alves C, Gusmão L, Abade A, Amorim A and Prata MJ (2001) Evidence for population sub-structuring in São Tomé e Príncipe as inferred from Y-chromosome STR analysis. Ann Hum Genet 65:271-283.

\section{Internet Resources}

IBGE - Instituto Brasileiro de Geografia Estatística. http://www.ibge.gov.br (March 10, 2009). 
STATISTICA - Data Analysis Software System. http://www.statsoft.com (July 18, 2009).

\section{Supplementary Material}

The following online material is available for this article:

Table S1 - Y chromosome haplotype distribution in the Manaus population sample $(\mathrm{N}=42)$.

Table S2 - Y chromosome haplotype distribution in the Ribeirão Preto population sample $(\mathrm{N}=65)$.

Table S3 - Y chromosome haplotype distribution in the Guinea Bissau population sample $(\mathrm{N}=32)$.
Table S4 - Y chromosome haplotype distribution in the Angola population sample $(\mathrm{N}=48)$.

Table S5 - Y chromosome haplotype distribution in the Mozambique population sample $(\mathrm{N}=36)$.

This material is available as part of the online article from http://www.scielo.br/gmb.

Associate Editor: Francisco Mauro Salzano

License information: This is an open-access article distributed under the terms of the Creative Commons Attribution License, which permits unrestricted use, distribution, and reproduction in any medium, provided the original work is properly cited. 
Table S1. Y chromosome haplotype distribution in the Manaus population sample (N=42).

\begin{tabular}{|c|c|c|c|c|c|c|c|c|c|c|}
\hline code & $\mathrm{n}$ & DYS19 & DYS389I & DYS389II & DYS390 & DYS391 & DYS392 & DYS393 & DYS385 & $\mathrm{HG}$ \\
\hline M1 & 1 & 14 & 13 & 29 & 24 & 11 & 13 & 13 & 10,13 & $\mathrm{~F}^{*}(\mathrm{xQ} 1 \mathrm{a} 3 \mathrm{a})-\mathrm{M} 213$ \\
\hline M2 & 1 & 15 & 12 & 28 & 22 & 10 & 11 & 13 & 12,12 & $F^{*}(x Q 1 a 3 a)-M 213$ \\
\hline M3 & 1 & 14 & 13 & 29 & 24 & 11 & 13 & 13 & 11,14 & $\mathrm{~F}^{*}(\mathrm{xQ} 1 \mathrm{a} 3 \mathrm{a})-\mathrm{M} 213$ \\
\hline M4 & 1 & 14 & 13 & 29 & 25 & 11 & 13 & 13 & 11,15 & $F^{*}(x Q 1 a 3 a)-M 213$ \\
\hline M5 & 1 & 14 & 14 & 31 & 23 & 10 & 11 & 12 & 13,16 & $F^{*}(x Q 1 a 3 a)-M 213$ \\
\hline M6 & 1 & 15 & 12 & 28 & 24 & 10 & 11 & 13 & 13,17 & $\mathrm{~F}^{*}(\mathrm{xQ} 1 \mathrm{a} 3 \mathrm{a})-\mathrm{M} 213$ \\
\hline M7 & 1 & 13 & 13 & 29 & 24 & 9 & 11 & 13 & 13,14 & E - M35 \\
\hline M8 & 1 & 14 & 12 & 30 & 25 & 10 & 14 & 13 & 13,17 & Q1a3a - M3 \\
\hline M9 & 1 & 14 & 12 & 28 & 23 & 10 & 11 & 13 & 13,14 & $\mathrm{~F}^{*}(\mathrm{xQ} 1 \mathrm{a} 3 \mathrm{a})-\mathrm{M} 213$ \\
\hline M10 & 1 & 14 & 12 & 28 & 24 & 12 & 13 & 13 & 11,14 & $\mathrm{~F}^{*}(\mathrm{xQ} 1 \mathrm{a} 3 \mathrm{a})-\mathrm{M} 213$ \\
\hline M11 & 1 & 14 & 13 & 31 & 22 & 10 & 11 & 12 & 13,16 & $F^{*}(x Q 1 a 3 a)-M 213$ \\
\hline M12 & 1 & 14 & 13 & 29 & 25 & 10 & 13 & 13 & 11,15 & $\mathrm{~F}^{*}(\mathrm{xQ} 1 \mathrm{a} 3 \mathrm{a})-\mathrm{M} 213$ \\
\hline M13 & 1 & 13 & 13 & 30 & 24 & 10 & 11 & 13 & 16,18 & E - M35 \\
\hline M14 & 1 & 13 & 14 & 30 & 23 & 10 & 14 & 13 & 14,16 & Q1a3a - M3 \\
\hline M15 & 1 & 13 & 13 & 30 & 24 & 10 & 14 & 13 & 13,16 & Q1a3a-M3 \\
\hline M16 & 1 & 15 & 13 & 29 & 22 & 10 & 13 & 12 & 11,15 & $\mathrm{~F}^{*}(\mathrm{xQ} 1 \mathrm{a} 3 \mathrm{a})-\mathrm{M} 213$ \\
\hline M17 & 1 & 15 & 13 & 28 & 24 & 10 & 13 & 13 & 12,13 & $\mathrm{~F}^{*}(\mathrm{xQ} 1 \mathrm{a} 3 \mathrm{a})-\mathrm{M} 213$ \\
\hline M18 & 1 & 14 & 13 & 29 & 23 & 10 & 11 & 12 & 14,16 & $\mathrm{~F}^{*}(\mathrm{xQ} 1 \mathrm{a} 3 \mathrm{a})-\mathrm{M} 213$ \\
\hline M19 & 1 & 13 & 13 & 29 & 25 & 9 & 11 & 13 & 13,14 & E - M35 \\
\hline M20 & 1 & 15 & 13 & 29 & 23 & 11 & 14 & 13 & 11,13 & $\mathrm{~F}^{*}(\mathrm{xQ} 1 \mathrm{a} 3 \mathrm{a})-\mathrm{M} 213$ \\
\hline M21 & 1 & 14 & 13 & 29 & 23 & 11 & 13 & 13 & 11,14 & $\mathrm{~F}^{*}(\mathrm{xQ} 1 \mathrm{a} 3 \mathrm{a})-\mathrm{M} 213$ \\
\hline M22 & 1 & 14 & 13 & 28 & 25 & 11 & 13 & 13 & 11,14 & $\mathrm{~F}^{*}(\mathrm{xQ} 1 \mathrm{a} 3 \mathrm{a})-\mathrm{M} 213$ \\
\hline M23 & 1 & 16 & 13 & 28 & 23 & 10 & 11 & 13 & 12,12 & $\mathrm{~F}^{*}(\mathrm{xQ} 1 \mathrm{a} 3 \mathrm{a})-\mathrm{M} 213$ \\
\hline M24 & 1 & 13 & 13 & 31 & 25 & 10 & 14 & 13 & 14,14 & Q1a3a - M3 \\
\hline M25 & 1 & 15 & 13 & 31 & 21 & 10 & 11 & 13 & 17,17 & E - M2 \\
\hline M26 & 1 & 18 & 13 & 31 & 23 & 10 & 14 & 13 & 15,18 & $F^{*}(x Q 1 a 3 a)-M 213$ \\
\hline M27 & 1 & 14 & 14 & 30 & 24 & 10 & 13 & 13 & 11,15 & $\mathrm{~F}^{*}(\mathrm{xQ} 1 \mathrm{a} 3 \mathrm{a})-\mathrm{M} 213$ \\
\hline M28 & 1 & 13 & 13 & 31 & 24 & 10 & 11 & 13 & 16,18 & E - M35 \\
\hline M29 & 1 & 14 & 13 & 29 & 25 & 11 & 14 & 13 & 12,14 & $\mathrm{~F}^{*}(\mathrm{xQ} 1 \mathrm{a} 3 \mathrm{a})-\mathrm{M} 213$ \\
\hline M30 & 1 & 14 & 13 & 29 & 24 & 12 & 13 & 13 & 11,14 & $\mathrm{~F}^{*}(\mathrm{xQ1a3a})-\mathrm{M} 213$ \\
\hline M31 & 1 & 14 & 13 & 29 & 23 & 11 & 13 & 12 & 11,15 & $\mathrm{~F}^{*}(\mathrm{xQ} 1 \mathrm{a} 3 \mathrm{a})-\mathrm{M} 213$ \\
\hline M32 & 1 & 14 & 12 & 28 & 23 & 10 & 12 & 13 & 14,14 & $\mathrm{~F}^{*}(\mathrm{xQ1a3a})-\mathrm{M} 213$ \\
\hline M33 & 1 & 15 & 13 & 30 & 24 & 10 & 12 & 14 & 15,15 & $\mathrm{~F}^{*}(\mathrm{xQ} 1 \mathrm{a} 3 \mathrm{a})-\mathrm{M} 213$ \\
\hline M34 & 1 & 15 & 13 & 29 & 25 & 11 & 13 & 13 & 12,14 & $F^{*}(x Q 1 a 3 a)-M 213$ \\
\hline M35 & 1 & 15 & 12 & 26 & 24 & 11 & 13 & 13 & 12,14 & $\mathrm{~F}^{*}(\mathrm{xQ} 1 \mathrm{a} 3 \mathrm{a})-\mathrm{M} 213$ \\
\hline M36 & 1 & 13 & 14 & 31 & 24 & 10 & 11 & 12 & 16,18 & E - M35 \\
\hline M37 & 1 & 13 & 13 & 28 & 24 & 11 & 13 & 13 & 11,14 & $\mathrm{~F}^{*}(\mathrm{xQ} 1 \mathrm{a} 3 \mathrm{a})-\mathrm{M} 213$ \\
\hline M38 & 1 & 13 & 13 & 29 & 24 & 11 & 13 & 13 & 12,14 & $F^{*}(x Q 1 a 3 a)-M 213$ \\
\hline M39 & 1 & 14 & 14 & 30 & 24 & 10 & 13 & 13 & 11,14 & $\mathrm{~F}^{*}(\mathrm{xQ} 1 \mathrm{a} 3 \mathrm{a})-\mathrm{M} 213$ \\
\hline M40 & 1 & 13 & 13 & 30 & 23 & 10 & 11 & 13 & 17,17 & E - M35 \\
\hline M41 & 1 & 14 & 14 & 31 & 23 & 9 & 11 & 13 & 12,14 & E - M35 \\
\hline M42 & 1 & 14 & 13 & 29 & 24 & 11 & 12 & 13 & 12,14 & $F^{*}(x Q 1 a 3 a)-M 213$ \\
\hline
\end{tabular}


Table S2. Y chromosome haplotype distribution in the Ribeirão Preto population sample (N=65).

\begin{tabular}{|c|c|c|c|c|c|c|c|c|c|c|}
\hline code & $\mathrm{n}$ & DYS19 & DYS389I & DYS389II & DYS390 & DYS391 & DYS392 & DYS393 & DYS385 & HG \\
\hline RP1 & 4 & 14 & 13 & 29 & 24 & 11 & 13 & 13 & $11-14$ & $\mathrm{~F}^{*}(\mathrm{xQ} 1 \mathrm{a} 3 \mathrm{a})-\mathrm{M} 213$ \\
\hline $\mathrm{RP} 2$ & 1 & 13 & 14 & 30 & 24 & 9 & 11 & 13 & $13-14$ & E1b1b1 - M35 \\
\hline RP3 & 1 & 15 & 12 & 28 & 25 & 11 & 11 & 12 & $18-18$ & $\mathrm{~F}^{*}(\mathrm{xQ} 1 \mathrm{a} 3 \mathrm{a})-\mathrm{M} 213$ \\
\hline RP4 & 1 & 15 & 13 & 29 & 24 & 11 & 13 & 13 & $11-13$ & $\mathrm{~F}^{*}(\mathrm{xQ} 1 \mathrm{a} 3 \mathrm{a})-\mathrm{M} 213$ \\
\hline RP5 & 2 & 14 & 13 & 29 & 24 & 11 & 13 & 13 & $11-11$ & $F^{*}(x Q 1 a 3 a)-M 213$ \\
\hline RP6 & 3 & 14 & 13 & 30 & 24 & 10 & 13 & 13 & $11-14$ & $F^{*}(x Q 1 a 3 a)-M 213$ \\
\hline RP7 & 1 & 15 & 13 & 30 & 24 & 10 & 12 & 15 & $14-15$ & $\mathrm{~F}^{*}(\mathrm{xQ} 1 \mathrm{a} 3 \mathrm{a})-\mathrm{M} 213$ \\
\hline RP8 & 1 & 14 & 13 & 30 & 24 & 10 & 11 & 12 & $13-17$ & $\mathrm{~F}^{*}(\mathrm{xQ} 1 \mathrm{a} 3 \mathrm{a})-\mathrm{M} 213$ \\
\hline RP9 & 1 & 14 & 13 & 29 & 23 & 10 & 13 & 14 & $11-14$ & $\mathrm{~F}^{*}(\mathrm{xQ} 1 \mathrm{a} 3 \mathrm{a})-\mathrm{M} 213$ \\
\hline RP10 & 1 & 14 & 13 & 28 & 24 & 11 & 13 & 13 & $11-13$ & $\mathrm{~F}^{*}(\mathrm{xQ} 1 \mathrm{a} 3 \mathrm{a})-\mathrm{M} 213$ \\
\hline RP11 & 1 & 15 & 13 & 29 & 22 & 11 & 13 & 12 & $11-14$ & $\mathrm{~F}^{*}(\mathrm{xQ} 1 \mathrm{a} 3 \mathrm{a})-\mathrm{M} 213$ \\
\hline RP12 & 1 & 15 & 13 & 29 & 24 & 11 & 13 & 13 & $11-14$ & $\mathrm{~F}^{*}(\mathrm{xQ} 1 \mathrm{a} 3 \mathrm{a})-\mathrm{M} 213$ \\
\hline RP13 & 1 & 14 & 13 & 30 & 24 & 10 & 13 & 13 & $11-11$ & $\mathrm{~F}^{*}(\mathrm{xQ} 1 \mathrm{a} 3 \mathrm{a})-\mathrm{M} 213$ \\
\hline RP14 & 1 & 15 & 12 & 28 & 24 & 10 & 14 & 13 & $14-16$ & $\mathrm{~F}^{*}(\mathrm{xQ} 1 \mathrm{a} 3 \mathrm{a})-\mathrm{M} 213$ \\
\hline RP15 & 1 & 15 & 13 & 29 & 24 & 10 & 13 & 13 & $12-14$ & $\mathrm{~F}^{*}(\mathrm{xQ} 1 \mathrm{a} 3 \mathrm{a})-\mathrm{M} 213$ \\
\hline RP16 & 1 & 15 & 13 & 30 & 24 & 9 & 11 & 13 & $17-17$ & E1b1b1 - M35 \\
\hline RP17 & 1 & 17 & 13 & 31 & 25 & 10 & 12 & 14 & $12-15$ & $\mathrm{~F}^{*}(\mathrm{xQ} 1 \mathrm{a} 3 \mathrm{a})-\mathrm{M} 213$ \\
\hline RP18 & 1 & 16 & 13 & 30 & 25 & 11 & 11 & 13 & $11-14$ & $\mathrm{~F}^{*}(\mathrm{xQ} 1 \mathrm{a} 3 \mathrm{a})-\mathrm{M} 213$ \\
\hline RP19 & 2 & 14 & 14 & 30 & 24 & 10 & 13 & 13 & $11-14$ & $\mathrm{~F}^{*}(\mathrm{xQ} 1 \mathrm{a} 3 \mathrm{a})-\mathrm{M} 213$ \\
\hline RP20 & 1 & 14 & 13 & 31 & 24 & 11 & 11 & 15 & $15-16$ & E1b1b1 - M35 \\
\hline RP21 & 1 & 13 & 13 & 30 & 24 & 9 & 11 & 13 & $17-17$ & E1b1b1 - M35 \\
\hline RP22 & 1 & 14 & 13 & 30 & 23 & 10 & 11 & 12 & $13-18$ & $\mathrm{~F}^{*}(\mathrm{xQ} 1 \mathrm{a} 3 \mathrm{a})-\mathrm{M} 213$ \\
\hline RP23 & 1 & 14 & 13 & 29 & 24 & 10 & 13 & 13 & $13-13$ & $\mathrm{~F}^{*}(\mathrm{xQ} 1 \mathrm{a} 3 \mathrm{a})-\mathrm{M} 213$ \\
\hline RP24 & 1 & 14 & 14 & 30 & 25 & 10 & 13 & 14 & $11-14$ & $\mathrm{~F}^{*}(\mathrm{xQ} 1 \mathrm{a} 3 \mathrm{a})-\mathrm{M} 213$ \\
\hline RP25 & 1 & 15 & 13 & 29 & 24 & 10 & 11 & 12 & $14-17$ & $\mathrm{~F}^{*}(\mathrm{xQ1a} 3 \mathrm{a})-\mathrm{M} 213$ \\
\hline RP26 & 1 & 14 & 13 & 30 & 24 & 10 & 13 & 14 & $14-14$ & $\mathrm{~F}^{*}(\mathrm{xQ} 1 \mathrm{a} 3 \mathrm{a})-\mathrm{M} 213$ \\
\hline RP27 & 1 & 15 & 12 & 30 & 22 & 10 & 11 & 14 & $14-15$ & $\mathrm{~F}^{*}(\mathrm{xQ} 1 \mathrm{a} 3 \mathrm{a})-\mathrm{M} 213$ \\
\hline RP28 & 1 & 14 & 13 & 29 & 25 & 10 & 13 & 13 & $11-14$ & $\mathrm{~F}^{*}(\mathrm{xQ} 1 \mathrm{a} 3 \mathrm{a})-\mathrm{M} 213$ \\
\hline RP29 & 1 & 15 & 12 & 28 & 24 & 10 & 11 & 12 & $13-18$ & $\mathrm{~F}^{*}(\mathrm{xQ1a} 3 \mathrm{a})-\mathrm{M} 213$ \\
\hline RP30 & 1 & 14 & 13 & 29 & 24 & 10 & 11 & 12 & $14-15$ & $\mathrm{~F}^{*}(\mathrm{xQ} 1 \mathrm{a} 3 \mathrm{a})-\mathrm{M} 213$ \\
\hline RP31 & 1 & 14 & 13 & 31 & 24 & 10 & 13 & 13 & $11-14$ & $\mathrm{~F}^{*}(\mathrm{xQ} 1 \mathrm{a} 3 \mathrm{a})-\mathrm{M} 213$ \\
\hline RP32 & 1 & 15 & 13 & 30 & 24 & 10 & 13 & 13 & $11-14$ & $\mathrm{~F}^{*}(\mathrm{xQ} 1 \mathrm{a} 3 \mathrm{a})-\mathrm{M} 213$ \\
\hline RP33 & 1 & 14 & 14 & 30 & 24 & 10 & 11 & 12 & $13-19$ & $\mathrm{~F}^{*}(\mathrm{xQ} 1 \mathrm{a} 3 \mathrm{a})-\mathrm{M} 213$ \\
\hline RP34 & 1 & 14 & 14 & 31 & 24 & 11 & 13 & 15 & $11-14$ & $\mathrm{~F}^{*}(\mathrm{xQ} 1 \mathrm{a} 3 \mathrm{a})-\mathrm{M} 213$ \\
\hline RP35 & 1 & 15 & 13 & 30 & 21 & 10 & 12 & 13 & $11-12$ & $\mathrm{~A}^{*}$ \\
\hline RP36 & 1 & 14 & 12 & 29 & 23 & 10 & 15 & 13 & $13-18$ & Q1a3a-M3 \\
\hline RP37 & 1 & 16 & 13 & 30 & 25 & 10 & 11 & 13 & $11-13$ & $\mathrm{~F}^{*}(\mathrm{xQ} 1 \mathrm{a} 3 \mathrm{a})-\mathrm{M} 213$ \\
\hline RP38 & 1 & 15 & 13 & 29 & 23 & 11 & 13 & 13 & $11-14$ & $\mathrm{~F}^{*}(\mathrm{xQ} 1 \mathrm{a} 3 \mathrm{a})-\mathrm{M} 213$ \\
\hline RP39 & 1 & 15 & 13 & 30 & 21 & 11 & 11 & 13 & $17-19$ & E1b1a - M2 \\
\hline RP40 & 1 & 17 & 14 & 30 & 25 & 10 & 11 & 13 & $14-17$ & E1b1b1 - M35 \\
\hline RP41 & 1 & 14 & 14 & 30 & 24 & 10 & 11 & 12 & $13-17$ & $\mathrm{~F}^{*}(\mathrm{xQ} 1 \mathrm{a} 3 \mathrm{a})-\mathrm{M} 213$ \\
\hline RP42 & 1 & 14 & 14 & 30 & 24 & 10 & 11 & 13 & $13-15$ & $\mathrm{~F}^{*}(\mathrm{xQ} 1 \mathrm{a} 3 \mathrm{a})-\mathrm{M} 213$ \\
\hline RP43 & 1 & 14 & 12 & 29 & 22 & 10 & 11 & 13 & $14-15$ & $\mathrm{~F}^{*}(\mathrm{xQ} 1 \mathrm{a} 3 \mathrm{a})-\mathrm{M} 213$ \\
\hline RP44 & 1 & 14 & 10 & 26 & 24 & 11 & 14 & 13 & $12-14$ & $\mathrm{~F}^{*}(\mathrm{xQ} 1 \mathrm{a} 3 \mathrm{a})-\mathrm{M} 213$ \\
\hline RP45 & 1 & 15 & 13 & 29 & 24 & 11 & 13 & 13 & $9-14$ & $\mathrm{~F}^{*}(\mathrm{xQ} 1 \mathrm{a} 3 \mathrm{a})-\mathrm{M} 213$ \\
\hline RP46 & 1 & 14 & 13 & 28 & 24 & 11 & 13 & 13 & $11-14$ & $\mathrm{~F}^{*}(\mathrm{xQ} 1 \mathrm{a} 3 \mathrm{a})-\mathrm{M} 213$ \\
\hline RP47 & 1 & 15 & 12 & 28 & 24 & 10 & 11 & 12 & $15-17$ & $F^{*}(x Q 1 a 3 a)-M 213$ \\
\hline RP48 & 1 & 13 & 14 & 31 & 24 & 10 & 11 & 13 & $13-15$ & $\begin{array}{l}\text { (A,EIDIa-b, F") - } \\
\text { SRY10831.1 }\end{array}$ \\
\hline RP49 & 1 & 14 & 13 & 29 & 24 & 10 & 13 & 13 & $11-14$ & $\mathrm{~F}^{*}(\mathrm{xQ} 1 \mathrm{a} 3 \mathrm{a})-\mathrm{M} 213$ \\
\hline RP50 & 1 & 15 & 12 & 28 & 22 & 10 & 11 & 13 & $13-14$ & $F^{*}(x Q 1 a 3 a)-M 213$ \\
\hline
\end{tabular}


Table S2. Y chromosome haplotype distribution in the Ribeirão Preto population sample (N=65) (Cont.).

\begin{tabular}{llllllllllc}
\hline RP51 & 1 & 14 & 12 & 28 & 23 & 10 & 12 & 13 & $11-14$ & $F^{*}(x Q 1 a 3 a)-M 213$ \\
RP52 & 1 & 15 & 12 & 27 & 25 & 10 & 14 & 13 & $13-16$ & $F^{*}(x Q 1 a 3 a)-M 213$ \\
RP53 & 1 & 14 & 14 & 30 & 24 & 11 & 13 & 13 & $10-13$ & $F^{*}(x Q 1 a 3 a)-M 213$ \\
RP54 & 1 & 16 & 13 & 29 & 23 & 11 & 12 & 14 & $15-16$ & $F^{*}(x Q 1 a 3 a)-M 213$ \\
RP55 & 1 & 13 & 14 & 31 & 24 & 11 & 11 & 12 & $16-18$ & E1b1b1 - M35 \\
RP56 & 1 & 15 & 12 & 29 & 25 & 10 & 11 & 12 & $13-17$ & $F^{*}(x Q 1 a 3 a)-M 213$ \\
RP57 & 1 & 14 & 12 & 28 & 25 & 10 & 13 & 13 & $11-14$ & $F^{*}(x Q 1 a 3 a)-M 213$ \\
RP58 & 1 & $14-15$ & 12 & 28 & 22 & 10 & 11 & 14 & $12-13$ & $F^{*}(x Q 1 a 3 a)-M 213$ \\
\hline
\end{tabular}


Table S3. Y chromosome haplotype distribution in the Guinea Bissau population sample (N=32).

\begin{tabular}{cccccccccc}
\hline code & n & DYS19 & DYS389I & DYS389II & DYS390 & DYS391 & DYS392 & DYS393 & DYS385 \\
\hline G1 & 1 & 13 & 13 & 31 & 24 & 10 & 12 & 14 & 16,17 \\
G2 & 1 & 14 & 13 & 30 & 23 & 10 & 11 & 14 & 11,14 \\
G3 & 1 & 15 & 12 & 29 & 22 & 11 & 11 & 13 & 14,14 \\
G4 & 1 & 15 & 13 & 30 & 21 & 10 & 11 & 14 & 14,14 \\
G5 & 1 & 15 & 13 & 30 & 21 & 10 & 11 & 15 & 16,16 \\
G6 & 1 & 15 & 13 & 30 & 22 & 11 & 11 & 13 & 15,15 \\
G7 & 1 & 15 & 13 & 31 & 21 & 10 & 11 & 13 & 16,17 \\
G8 & 1 & 15 & 13 & 31 & 21 & 10 & 11 & 13 & 16,19 \\
G9 & 1 & 15 & 13 & 32 & 21 & 10 & 11 & 14 & 15,16 \\
G10 & 1 & 15 & 13 & 32 & 21 & 11 & 11 & 14 & 15,15 \\
G11 & 1 & 15 & 14 & 30 & 21 & 10 & 11 & 14 & 16,18 \\
G12 & 2 & 15 & 14 & 31 & 21 & 10 & 11 & 14 & 14,14 \\
G13 & 1 & 15 & 14 & 32 & 23 & 11 & 11 & 13 & 17,17 \\
G14 & 1 & 15 & 15 & 32 & 22 & 10 & 11 & 14 & 14,16 \\
G15 & 1 & 16 & 12 & 30 & 22 & 10 & 11 & 13 & 14,16 \\
G16 & 1 & 16 & 12 & 30 & 22 & 11 & 11 & 13 & 15,17 \\
G17 & 1 & 16 & 13 & 29 & 21 & 10 & 11 & 14 & 15,15 \\
G18 & 1 & 16 & 13 & 30 & 21 & 10 & 11 & 13 & 16,17 \\
G19 & 1 & 16 & 13 & 30 & 21 & 10 & 11 & 14 & 17,17 \\
G20 & 1 & 16 & 13 & 30 & 21 & 10 & 12 & 15 & 16,17 \\
G21 & 1 & 16 & 14 & 30 & 21 & 10 & 11 & 14 & 17,17 \\
G22 & 1 & 16 & 14 & 30 & 22 & 10 & 11 & 13 & 17,17 \\
G23 & 1 & 17 & 12 & 29 & 22 & 10 & 11 & 13 & 14,17 \\
G24 & 1 & 17 & 13 & 30 & 20 & 10 & 11 & 14 & 15,17 \\
G25 & 1 & 17 & 13 & 30 & 21 & 10 & 11 & 14 & 16,18 \\
G26 & 1 & 17 & 13 & 31 & 20 & 11 & 11 & 15 & 16,16 \\
G27 & 1 & 17 & 14 & 31 & 22 & 10 & 11 & 13 & 15,16 \\
G28 & 3 & 17 & 14 & 31 & 22 & 10 & 11 & 13 & 16,17 \\
G29 & 1 & 17 & 14 & 31 & 22 & 10 & 11 & 13 & 17,17 \\
\hline & & & & & & & & &
\end{tabular}


Table S4. Y chromosome haplotype distribution in the Angola population sample $(\mathrm{N}=48)$.

\begin{tabular}{|c|c|c|c|c|c|c|c|c|c|}
\hline code & $\mathrm{n}$ & DYS19 & DYS389I & DYS389II & DYS390 & DYS391 & DYS392 & DYS393 & DYS385 \\
\hline A1 & 2 & 14 & 12 & 28 & 25 & 10 & 11 & 13 & 14,20 \\
\hline A2 & 1 & 14 & 12 & 28 & 25 & 11 & 11 & 13 & 14,20 \\
\hline A3 & 1 & 14 & 12 & 28 & 26 & 11 & 11 & 13 & 14,19 \\
\hline A4 & 1 & 14 & 13 & 30 & 21 & 10 & 11 & 14 & 14,19 \\
\hline A5 & 2 & 15 & 12 & 28 & 22 & 10 & 11 & 14 & 12,13 \\
\hline A6 & 1 & 15 & 12 & 29 & 21 & 10 & 11 & 14 & 16,17 \\
\hline A7 & 1 & 15 & 13 & 30 & 21 & 10 & 11 & 13 & 15,18 \\
\hline A8 & 1 & 15 & 13 & 30 & 21 & 10 & 11 & 13 & 16,17 \\
\hline A9 & 1 & 15 & 13 & 30 & 21 & 10 & 11 & 13 & 16,18 \\
\hline A10 & 2 & 15 & 13 & 30 & 21 & 10 & 11 & 13 & 17,17 \\
\hline A11 & 1 & 15 & 13 & 30 & 21 & 10 & 11 & 14 & 12,16 \\
\hline A12 & 1 & 15 & 13 & 30 & 21 & 10 & 11 & 14 & 14,18 \\
\hline A13 & 1 & 15 & 13 & 30 & 21 & 10 & 11 & 14 & 15,16 \\
\hline A14 & 2 & 15 & 13 & 30 & 21 & 11 & 11 & 13 & 16,17 \\
\hline A 15 & 1 & 15 & 13 & 30 & 21 & 11 & 11 & 14 & 16,17 \\
\hline A16 & 1 & 15 & 13 & 31 & 21 & 10 & 11 & 13 & 15,15 \\
\hline A17 & 1 & 15 & 13 & 31 & 21 & 10 & 11 & 13 & 15,17 \\
\hline A18 & 1 & 15 & 13 & 31 & 21 & 10 & 11 & 13 & 16,16 \\
\hline A19 & 2 & 15 & 13 & 31 & 21 & 10 & 11 & 13 & 16,17 \\
\hline A20 & 1 & 15 & 13 & 31 & 21 & 10 & 11 & 13 & 17,17 \\
\hline A21 & 1 & 15 & 13 & 31 & 21 & 10 & 11 & 13 & 17,18 \\
\hline A22 & 2 & 15 & 13 & 31 & 21 & 11 & 11 & 13 & 16,17 \\
\hline A23 & 1 & 15 & 13 & 31 & 21 & 12 & 11 & 13 & 16,17 \\
\hline A24 & 1 & 15 & 14 & 30 & 24 & 12 & 13 & 13 & 16,17 \\
\hline A25 & 1 & 15 & 14 & 31 & 21 & 10 & 11 & 13 & 15,19 \\
\hline A26 & 1 & 15 & 14 & 32 & 21 & 11 & 11 & 13 & 15,17 \\
\hline $\mathrm{A} 27$ & 1 & 15 & 14 & 32 & 24 & 10 & 11 & 13 & 11,11 \\
\hline A28 & 1 & 15 & 14 & 33 & 21 & 10 & 11 & 13 & 15,20 \\
\hline A29 & 1 & 16 & 12 & 30 & 24 & 10 & 11 & 13 & 11,11 \\
\hline A30 & 1 & 16 & 13 & 29 & 21 & 10 & 11 & 15 & 16,16 \\
\hline A31 & 1 & 16 & 13 & 30 & 21 & 10 & 11 & 14 & 15,17 \\
\hline A32 & 1 & 16 & 13 & 30 & 21 & 10 & 11 & 14 & 18,18 \\
\hline A33 & 1 & 16 & 13 & 30 & 21 & 11 & 11 & 13 & 17,17 \\
\hline A34 & 1 & 16 & 13 & 30 & 21 & 11 & 11 & 14 & 16,18 \\
\hline A35 & 1 & 16 & 13 & 31 & 21 & 10 & 11 & 15 & 16,17 \\
\hline A36 & 1 & 16 & 13 & 31 & 21 & 11 & 11 & 13 & 17,17 \\
\hline A37 & 1 & 16 & 14 & 31 & 21 & 10 & 11 & 15 & 16,20 \\
\hline A38 & 1 & 16 & 14 & 32 & 25 & 10 & 11 & 13 & 11,11 \\
\hline A39 & 1 & 17 & 13 & 30 & 21 & 11 & 11 & 15 & 17,19 \\
\hline A40 & 1 & 17 & 13 & 30 & 21 & 11 & 11 & 15 & 18,19 \\
\hline A41 & 1 & 17 & 14 & 31 & 21 & 10 & 11 & 15 & 16,18 \\
\hline A42 & 1 & 17 & 14 & 32 & 21 & 10 & 11 & 13 & 17,18 \\
\hline
\end{tabular}


Table S5. Y chromosome haplotype distribution in the Mozambique population sample ( $\mathrm{N}=36)$.

\begin{tabular}{cccccccccc}
\hline code & n & DYS19 & DYS389I & DYS389II & DYS390 & DYS391 & DYS392 & DYS393 & DYS385 \\
\hline Mo1 & 1 & 12 & 13 & 30 & 21 & 10 & 11 & 14 & 17,18 \\
Mo2 & 1 & 13 & 11 & 29 & 23 & 11 & 11 & 14 & 16,16 \\
Mo3 & 1 & 14 & 12 & 28 & 24 & 11 & 11 & 13 & 13,19 \\
Mo4 & 2 & 14 & 12 & 28 & 24 & 11 & 11 & 13 & 14,19 \\
Mo5 & 1 & 14 & 12 & 28 & 27 & 10 & 11 & 13 & 13,19 \\
Mo6 & 2 & 14 & 13 & 30 & 21 & 11 & 11 & 14 & 16,16 \\
Mo7 & 1 & 14 & 13 & 31 & 23 & 10 & 10 & 14 & 14,17 \\
Mo8 & 1 & 15 & 12 & 26 & 20 & 10 & 11 & 13 & 15,17 \\
Mo9 & 1 & 15 & 12 & 30 & 21 & 10 & 11 & 13 & 17,18 \\
Mo10 & 1 & 15 & 13 & 30 & 21 & 10 & 11 & 13 & 16,17 \\
Mo11 & 1 & 15 & 13 & 30 & 21 & 10 & 11 & 14 & 16,16 \\
Mo12 & 1 & 15 & 13 & 30 & 21 & 10 & 11 & 14 & 17,17 \\
Mo13 & 1 & 15 & 13 & 30 & 21 & 11 & 11 & 13 & 16,17 \\
Mo14 & 1 & 15 & 13 & 30 & 21 & 12 & 11 & 14 & 16,17 \\
Mo15 & 1 & 15 & 13 & 31 & 21 & 10 & 11 & 13 & 16,16 \\
Mo16 & 1 & 15 & 13 & 31 & 21 & 10 & 11 & 13 & 16,18 \\
Mo17 & 1 & 15 & 13 & 31 & 21 & 10 & 11 & 14 & 15,20 \\
Mo18 & 1 & 15 & 14 & 28 & 25 & 11 & 11 & 13 & 10,15 \\
Mo19 & 1 & 15 & 14 & 31 & 21 & 10 & 11 & 13 & 15,17 \\
Mo20 & 1 & 15 & 14 & 31 & 21 & 11 & 11 & 14 & 15,20 \\
Mo21 & 1 & 15 & 14 & 32 & 24 & 10 & 11 & 13 & 11,11 \\
Mo22 & 1 & 15 & 14 & 32 & 24 & 10 & 12 & 15 & 11,12 \\
Mo23 & 1 & 15 & 14 & 32 & 24 & 11 & 11 & 13 & 11,11 \\
Mo24 & 1 & 15 & 14 & 33 & 24 & 10 & 13 & 13 & 11,12 \\
Mo25 & 1 & 16 & 12 & 28 & 25 & 10 & 11 & 13 & 11,14 \\
Mo26 & 1 & 16 & 13 & 30 & 20 & 10 & 11 & 16 & 16,18 \\
Mo27 & 1 & 16 & 14 & 31 & 21 & 10 & 11 & 14 & 17,18 \\
Mo28 & 1 & 16 & 14 & 32 & 24 & 11 & 11 & 13 & 10,11 \\
Mo29 & 1 & 17 & 13 & 30 & 21 & 10 & 11 & 14 & 16,16 \\
Mo30 & 1 & 17 & 13 & 30 & 21 & 10 & 11 & 14 & 16,17 \\
Mo31 & 1 & 17 & 13 & 30 & 21 & 10 & 11 & 14 & 17,17 \\
Mo32 & 1 & 17 & 13 & 30 & 25 & 10 & 11 & 15 & 17,18 \\
Mo33 & 1 & 17 & 13 & 31 & 21 & 10 & 11 & 14 & 17,18 \\
Mo34 & 1 & 17 & 15 & 32 & 21 & 10 & 11 & 14 & 15,19 \\
\hline & & & & & & & & &
\end{tabular}

